\title{
TLC Method for Simultaneous Quantification of Chlorzoxazone, Paracetamol, Famotidine and Diclofenac Potassium in their Combined Dosage Form
}

\author{
Chhalotiya UK*, Patel DB, Shah DA, Mehta FA \\ and Bhatt KK \\ Department of Pharmaceutical Chemistry and Analysis, \\ Indukaka Ipcowala College of Pharmacy, India \\ *Corresponding author: Usmangani K. Chhalotiya, \\ Department of Pharmaceutical Chemistry and Analysis, \\ Indukaka Ipcowala College of Pharmacy, India
}

Received: December 15, 2016; Accepted: January 02, 2017; Published: January 05, 2017

\begin{abstract}
Asensitive, selective and precise high performance thin layerchromatographic method has been developed for the estimation of chlorzoxazone, paracetamol, diclofenac potassium and famotidine in their pharmaceutical dosage form. TLC aluminum plates pre-coated with silica gel $60 \mathrm{~F}_{254}$ used as the stationary phase, while chloroform: methanol: ethyl acetate: hexane: ammonia (10:2.5:1.5:1:0.1, $\mathrm{v} / \mathrm{v} / \mathrm{v} / \mathrm{v} / \mathrm{v}$ ) used as mobile phase. The RF values were observed $0.74 \pm 0.01$, $0.52 \pm 0.01,0.30 \pm 0.01$ and $0.14 \pm 0.01$ for chlorzoxazone, paracetamol, diclofenac potassium and famotidine respectively. The densitometric analysis was carried out in absorbance mode at $282 \mathrm{~nm}$. The method was linear in the range of 250-1500 ng/band for chlorzoxazone, diclofenac potassium and famotidine and $500-3000 \mathrm{ng} / \mathrm{band}$ for paracetamol and method was validated as per $\mathrm{ICH}$ guideline. The limit of detection and limit of quantitation were found to be 35.98 $\mathrm{ng} / \mathrm{spot}$ and $109.05 \mathrm{ng} / \mathrm{b}$ and respectively for chlorzoxazone, $99.74 \mathrm{ng} / \mathrm{band}$ and $302.25 \mathrm{ng} / \mathrm{band}$ respectively for paracetamol, $58.63 \mathrm{ng} / \mathrm{band}$ and 177.69 $\mathrm{ng} /$ band respectively for diclofenac and $50.93 \mathrm{ng} /$ band and $154.35 \mathrm{ng} / \mathrm{band}$ respectively for famotidine. The proposed method was successfully applied to the quantification of chlorzoxazone, paracetamol, diclofenac potassium and famotidine in their pharmaceutical dosage form.
\end{abstract}

Keywords: Chlorzoxazone; Paracetamol; Diclofenac potassium; Famotidine; High performance thin layer chromatography; Validation

\section{Abbreviations}

CLZ: Chlorzoxazone; PCM: Paracetamol; DCL: Diclofenac Potassium; FAM: Famotidine; HPTLC: High Performance Thin Layer Chromatography

\section{Introduction}

Chlorzoxazone (CLZ) is chemically 5-chloro-2,3-dihydro-1,3benzoxazol-2-one. The empirical formula of $\mathrm{CLZ}$ is $\mathrm{C}_{7} \mathrm{H}_{4} \mathrm{ClNO}_{2}$ and a molecular weight is $169.56 \mathrm{~g} / \mathrm{mol}$. It is NSAID. It inhibits multisynaptic reflex a.c. involved in producing and maintaining skeletal muscle spasm. Paracetamol (PCM) is chemically N-(4hydroxyphenyl) acetamide. The empirical formula for PCM is $\mathrm{C}_{8} \mathrm{H}_{9} \mathrm{NO}_{2}$ and a molecular weight is $151.163 \mathrm{~g} / \mathrm{mol}$. It inhibiting both isoforms of cyclooxygenase, COX-1, COX-2 and COX-3 enzymes involved in Prostaglandin (PG) synthesis. Diclofenac Potassium (DCL) is chemically 2-\{2-[(2,6-dichlorophenyl)amino]phenyl $\}$ acetic acid and empirical formula of DCL is $\mathrm{C}_{14} \mathrm{H}_{11} \mathrm{Cl}_{2} \mathrm{NO}_{2}$ and molecular weight is $318.13 \mathrm{~g} / \mathrm{mol}$. It inhibition of leukocyte migration and the enzyme cylooxygenase (COX-1 and COX-2), leading to the peripheral inhibition of prostaglandin synthesis. Famotidine (FAM) is chemically $3-[(\{2-[($ diaminomethylidene $)$ amino $]-1,3-$ thiazol-4yl\}methyl)sulfanyl]-N' sulfamoylpropanimidamide and empirical formula for FAM is $\mathrm{C}_{8} \mathrm{H}_{15} \mathrm{~N}_{7} \mathrm{O}_{2} \mathrm{~S}_{3}$ and molecular weight is $337.44 \mathrm{~g} /$ mol. It is competitive histamine $\mathrm{H}_{2}$-receptor antagonist and inhibits many of the isoenzymes of the hepatic CYP450 enzyme system.

The combined dosage form of CLZ, PCM, DCL and FAM is used as muscle relaxant. CLZ, PCM, DCL and FAM are official in United State Pharmacopoeia and British Pharmacopoeia. Official method has been reported for CLZ, PCM, DCL and FAM in United State Pharmacopoeia and British Pharmacopoeia. Some of UV, HPLC, TLC methods has been reported for the estimation of CLZ, PCM, DCL and FAM alone and with other drug combination. Till date no HPTLC method has been reported for the quantification of CLZ, PCM, DCL and FAM in their combined dosage form [1-27]. In comparison to LC and LC-MS/MS methods, HPTLC method is considered to be a good alternative and it should be widely explored as an important tool in routine drug analysis. A major advantage of HPTLC is its ability to analyze several samples simultaneously using a small quantity of mobile phase. This reduces the time and cost of analysis.

The aim of the present work was to develop an sensitive, accurate, repeatable and specific HPTLC method for the determination of CLZ, PCM, DCL and FAM both as a bulk drug and in formulation. There is no HPTLC method reported for the quantification of CLZ, PCM, DCL and FAM in combination so attempt have been made to develop High Performance Thin Layer Chromatographic method. The proposed method was validated according to ICH guidelines [28] and its updated international convention.

\section{Experimental}

\section{HPTLC instrument}

The samples were applied in the form of a bands of width $8 \mathrm{~mm}$
Austin Chromatogr - Volume 4 Issue 1 - 2017 ISSN 2379-7975 | www.austinpublishing group.com Chhalotiya et al. @ All rights are reserved
Citation: Chhalotiya UK, Patel DB, Shah DA, Mehta FA and Bhatt KK. TLC Method for Simultaneous Quantification of Chlorzoxazone, Paracetamol, Famotidine and Diclofenac Potassium in their Combined Dosage Form. Austin Chromatogr. 2017; 4(1): 1044 
with a Camag $100 \mu \mathrm{l}$ sample syringe (Hamilton, Switzerland) using Camag Linomat 5 (Switzerland) sample applicator on pre-coated silica gel aluminum plate $60 \mathrm{~F}_{254}\left(10 \times 10 \mathrm{~cm}^{2}\right.$ with $0.2 \mathrm{~mm}$ thickness, E. Merck, Germany). Camag TLC scanner 4 was used for the densitometric scanning.

\section{Chemicals and reagents}

Analytically pure CLZ, PCM, DCL and FAM from Sun pharmaceutical industry ltd., Vadodara, India were obtained as gift samples. Methanol (AR grade) of SRL Private Ltd. and chloroform of Chemdyes Corporation (AR grade) were used. Ammonia and hexane of Chiti-Chem Corporation (AR grade) were used. Ethyl acetate of Astron Chemicals (AR grade) Tablet formulation fastran MR (Horizon biocauticals Pvt. Ltd.) containing $500 \mathrm{mg}$ of PCM, $250 \mathrm{mg}$ CLZ, $50 \mathrm{mg}$ DCL and $10 \mathrm{mg}$ FAM was procured from local pharmacy.

\section{Chromatographic System}

\section{Sample application}

Standards and formulation samples of CLZ, PCM, DCL and FAM were applied on the HPTLC plates in the form of narrow bands of $6 \mathrm{~mm}$ length, $10 \mathrm{~mm}$ from the bottom and left edge and with 9 $\mathrm{mm}$ distance between two bands. Samples were applied under a continuous stream of nitrogen gas.

\section{Mobile phase and development}

Plates were developed using a mobile phase consisting of chloroform: methanol: ethyl acetate: hexane: ammonia (10:2.5:1.5:1:0.1, v/v/v/v/v). Linear ascending development was carried out in a twin-trough glass chamber equilibrated with the mobile phase vapors for $30 \mathrm{~min}$ at $25 \pm 2^{\circ} \mathrm{C}$. Ten milliliters of the mobile phase $(5 \mathrm{ml}$ in the trough containing the plate and $5 \mathrm{ml}$ in the other trough) was used for each development and was allowed to migrate a distance of $80 \mathrm{~mm}$, sample application rate is $200 \mathrm{nl} / \mathrm{sec}$. After development, the HPTLC plates were dried completely using continuous stream of nitrogen.

\section{Densitometric analysis}

Densitometric scanning was performed in the absorbance mode under control by winCATS planar chromatography software. The source of radiation was the deuterium lamp and bands were scanned at $282 \mathrm{~nm}$. The slit dimensions were $6 \mathrm{~mm}$ length and 0.45 $\mathrm{mm}$ width, with a scanning rate of $20 \mathrm{~mm} / \mathrm{s}$. Concentrations of the compound were determined from the intensity of diffusely reflected light and evaluated as peak areas against concentrations using a linear regression equation.

\section{Preparation of standard stock solution}

PCM (10 mg), CLZ (5 mg), DCL (5mg) and FAM (5mg) were accurately weighed and transferred to $10 \mathrm{ml}$ volumetric flasks and dissolved in few $\mathrm{ml}$ of methanol. Volumes were made up to the mark with methanol to yield a solution containing $1000 \mu \mathrm{g} / \mathrm{ml}$ of PCM and $500 \mu \mathrm{g} / \mathrm{ml}$ of CLZ, DCL and FAM. Aliquot from the stock solutions of PCM, CLZ, DCL and FAM were appropriately diluted with mobile phase to obtain working standard of $100 \mu \mathrm{g} / \mathrm{ml}$ of PCM and $50 \mu \mathrm{g} / \mathrm{ml}$ of CLZ, DCL and FAM respectively.

\section{Validation}

Validation of the developed HPTLC method was carried out according to International Conference on Harmonization (ICH) guidelines Q2 (R1) for specificity, sensitivity, accuracy, precision, repeatability and robustness [28].

\section{Linearity of calibration curves}

Linearity of the method was evaluated by constructing calibration curves at six concentration levels over a range of 500-3000 ng/band for PCM and 250-1500 ng/band for CLZ, DCL and FAM by applying $5 \mu \mathrm{l}$ to $30 \mu \mathrm{l}$ from stock solution has been applied on HPTLC plate using sample applicator. The calibration curves were developed by plotting peak area versus concentration $(n=6)$ with the help of the winCATS software.

\section{Accuracy}

Accuracy is closeness of the test results obtained by the method to the true value and should be established across specified range of analytical Procedure. The accuracy of the method was determined by calculating recoveries of PCM, CLZ, DCL and FAM by method of standard additions respectively. Known amount of PCM $(0,500$, $1000,1500 \mathrm{ng} / \mathrm{spot})$ and $\mathrm{AML}(0,250,500,750 \mathrm{ng} / \mathrm{spot})$ were taken from the working standard solutions $(100 \mu \mathrm{g} / \mathrm{ml}$ of PCM and $50 \mu \mathrm{g} / \mathrm{ml}$ of CLZ, DCL and FAM respectively). It was added to a pre quantified sample and the amount of PCM, CLZ, DCL and FAM were estimated by measuring the peak area and by fitting these values to the straightline equation of calibration curve. The proposed acceptance criteria for the accuracy studies are ranges from $95-105 \%$.

\section{Precision}

Precision was evaluated in terms of intraday and intraday precisions. Working standard solutions of $100 \mu \mathrm{g} / \mathrm{ml}$ of PCM and $50 \mu \mathrm{g} / \mathrm{ml}$ of CLZ, DCL and FAM, were prepared and used for the precision study. Intraday precision was determined by analyzing sample solutions of PCM, CLZ, DCL and FAM at three levels covering low, medium and high concentrations of the calibration curve three times on the same day. Intraday precision was determined by analyzing sample solutions of PCM, CLZ, DCL and FAM at three levels covering low, medium and high concentrations over a period of 3 days. The peak areas obtained were used to calculate mean and RSD values. Less than $5 \%$ RSD values indicate that the method is precise.

\section{Specificity}

Specificity is the ability to assess unequivocally the analytes in the presence of components which may be expected to be present. The specificity of the method was ascertained by analyzing PCM, CLZ, DCL and FAM in presence of excipients commonly used for tablet formulations. The bands of PCM, CLZ, DCL and FAM were confirmed by comparing RF values and respective spectra of sample with those of standards. The peak purity of PCM, CLZ, DCL and FAM was assured by comparing the spectra at three different levels, that is, peak start, peak apex and peak end positions.

\section{Sensitivity}

Sensitivity of the method was determined with respect to LOD and LOQ. Noise was determined by scanning a blank band (methanol) six times. LOD was calculated as 3 times the noise level and LOQ was calculated as 10 times the noise level.

\section{Robustness}

Small changes in the chamber saturation time, solvent migration 


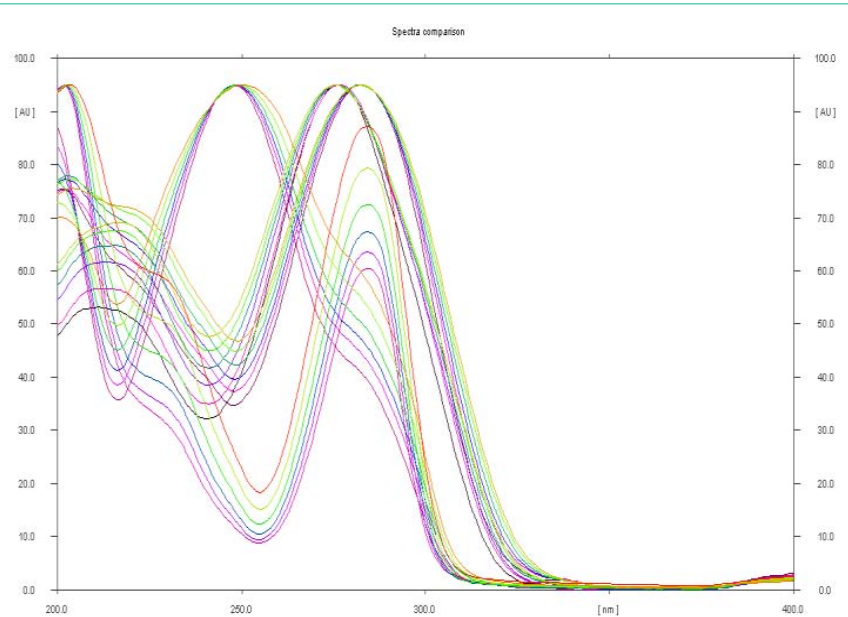

Figure 1: Overlain UV spectra of PCM, CLZ, FAM and DCL $(200-400$ nm).

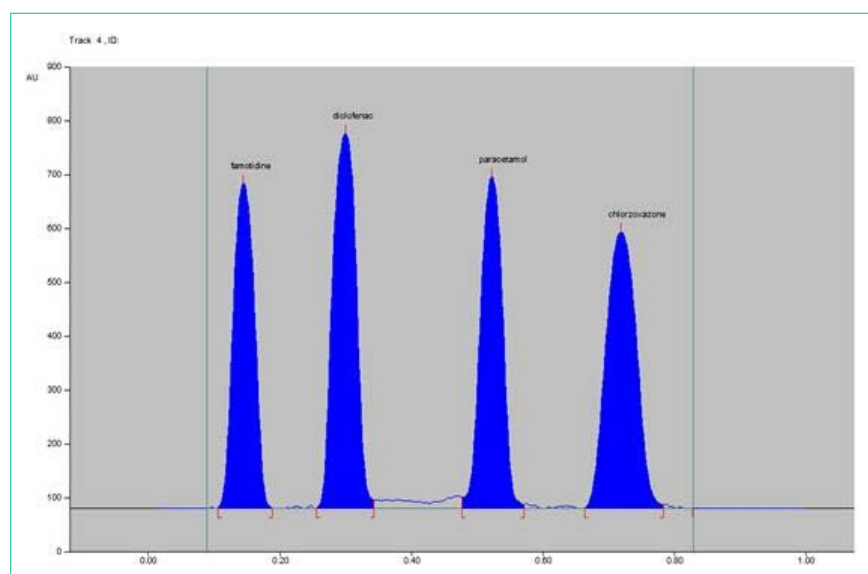

Figure 2: Densitogram of CLZ, PCM, DCL and FAM using mobile phase chloroform: methanol: ethyl acetate: hexane: ammonia (10:2.5:1.5:1:0.1, $\mathrm{v} / \mathrm{v} / \mathrm{v} / \mathrm{v} / \mathrm{v})$.

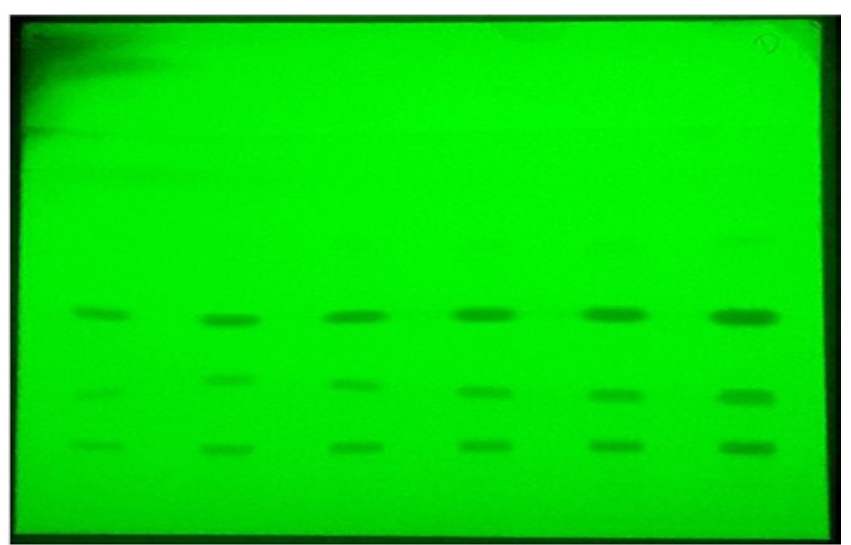

Figure 3: Photograph of developed HPTLC plate.

distance and mobile phase composition were introduced and the effects on the results were examined. Robustness of the method was determined in triplicate at a concentration level of $2000 \mathrm{ng} / \mathrm{band}$ for PCM and 1000 ng/band for DCL and 750 ng/band for CLZ and FAM. The mean and RSD of peak areas were calculated.

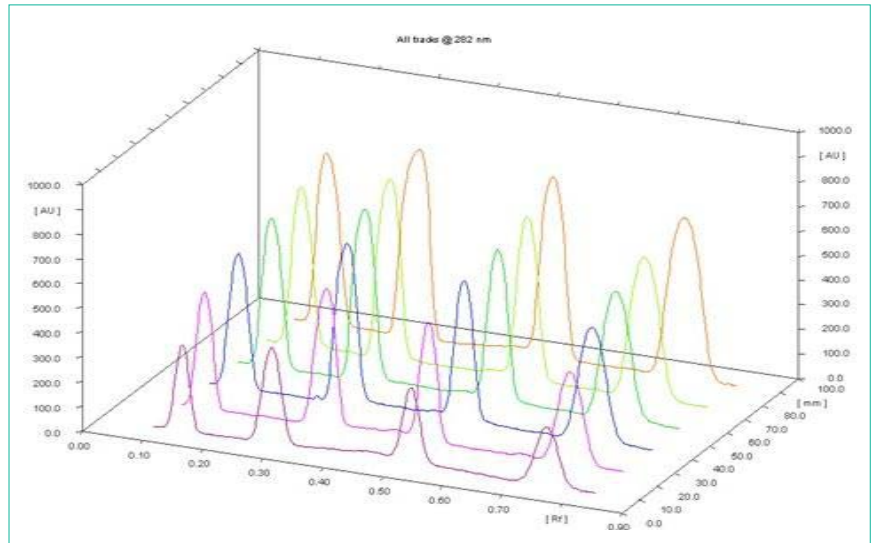

Figure 4: Three dimensional overlay of HPTLC densitograms of calibration bands of CLZ, PCM, DCL and FAM.

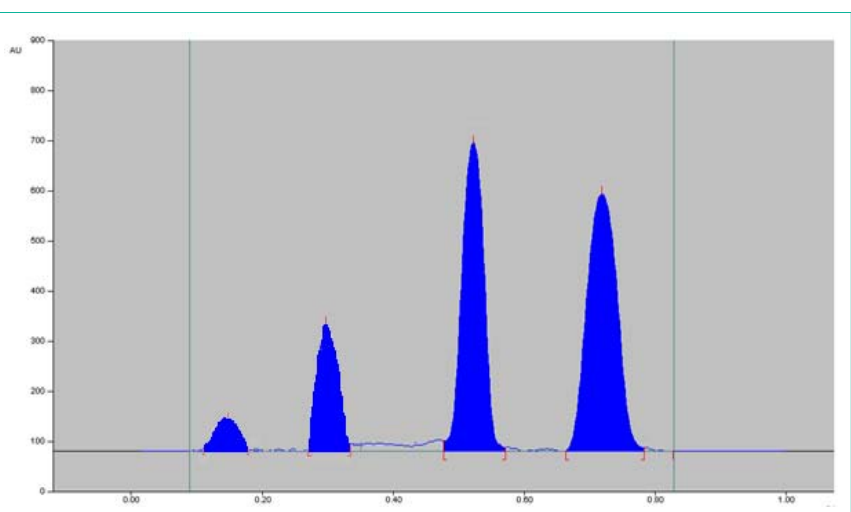

Figure 5: Densitogram of analysis of marketed formulation of PCM (1500 ng/ spot), CLZ (750 ng/spot), FAM (300 ng/spot) and DCL (1500 ng/spot).

\section{Analysis of marketed formulations}

Twenty tablets were weighed accurately and finely powdered. Tablet powder equivalent to $500 \mathrm{mg}$ of PCM, $250 \mathrm{mg}$ of CLZ, $50 \mathrm{mg}$ of DCL and $10 \mathrm{mg}$ of FAM was accurately weighed and transferred to a $100 \mathrm{ml}$ volumetric flask. A few $\mathrm{ml}(40 \mathrm{ml})$ of methanol was added to the above flask and flask was sonicated for $15 \mathrm{~min}$. The solution was filtered using what man filter paper No. 41 in another $100 \mathrm{ml}$ volumetric flask and make up the volume up to the mark with the methanol.

A solution containing $300 \mathrm{ng} / \mathrm{b}$ and FAM and $1500 \mathrm{ng} / \mathrm{band}$ DCL were injected as per the above chromatographic conditions and peak areas were recorded. Appropriate volume of the aliquot was transferred to a $10 \mathrm{ml}$ volumetric flask and the volume was made up to the mark with the mobile phase to obtain a solution containing $750 \mathrm{ng} / \mathrm{b}$ and CLZ and $1500 \mathrm{ng} / \mathrm{band}$ PCM. The quantifications were carried out by keeping these values to the straight line equation of calibration curve.

\section{Results and Discussion}

\section{Optimization of the mobile phase}

To develop the HPTLC method for analysis of PCM, CLZ, DCL and FAM in the pharmaceutical dosage form for routine analysis, selection of the mobile phase was carried out on the basis of polarity. A mobile phase that would give a dense and compact band with an 
Table 1: Regression analysis of calibration curve.

\begin{tabular}{|c|c|c|c|c|}
\hline Parameters & CLZ & PCM & DCL & FAM \\
\hline Linearity range (ng/spot) & $250-1500$ & $500-3000$ & $250-1500$ & $250-1500$ \\
\hline Slope & 14.3 & 5.7 & 10.9 & 10.8 \\
\hline Standard deviation of slope & 0.21 & 0.03 & 0.22 & 0.30 \\
\hline Intercept & 4619.6 & 4953.4 & 9033.6 & 4310.6 \\
\hline Standard deviation of intercept & 155.71 & 171.73 & 193.72 & 166.82 \\
\hline Correlation coefficient & 0.995 & 0.997 & 0.995 & 0.996 \\
\hline
\end{tabular}

Table 2: Summary of validation parameter.

\begin{tabular}{|c|c|c|c|}
\hline Parameters & CLZ & PCM & DCL \\
\hline RF & 0.74 & 0.52 & 0.29 \\
\hline Detection limit (ng/band) & 35.98 & 99.74 & 58.63 \\
\hline Quantitation limit (ng/band) & 109.05 & 302.25 & 177.69 \\
\hline Accuracy (\%) & $98.81-99.57$ & $98.55-99.88$ & $99.22-100.27$ \\
\hline Intra-day (n=3) (\% RSD) & $1.18-1.249$ & $0.94-1.31$ & $1.33-1.60$ \\
\hline Inter-day (n=3) (\% RSD) & $1.71-1.89$ & $1.45-1.68$ & $1.44-1.83$ \\
\hline Repeatability study (n=6) (\% RSD) & $1.77-1.96$ & $1.77-1.86$ & $1.57-1.93$ \\
\hline
\end{tabular}

Table 3: Robustness Study of proposed method.

\begin{tabular}{|c|c|c|c|c|c|c|c|c|}
\hline \multirow[t]{2}{*}{ Parameters } & \multicolumn{2}{|c|}{$\begin{array}{c}\text { PCM } \\
(2000 \mathrm{ng} / \text { band })\end{array}$} & \multicolumn{2}{|c|}{$\begin{array}{c}\text { CLZ } \\
\text { (1000 ng/band) }\end{array}$} & \multicolumn{2}{|c|}{$\begin{array}{c}\text { FAM } \\
(1000 \mathrm{ng} / \text { band })\end{array}$} & \multicolumn{2}{|c|}{$\begin{array}{c}\text { DCL } \\
(1000 \mathrm{ng} / \text { band })\end{array}$} \\
\hline & $\mathrm{RF}$ mean $\pm \mathrm{SD}$ & $\%$ RSD & $\mathrm{RF}$ mean $\pm S D$ & $\%$ RSD & RF mean $\pm S D$ & \%RSD & RF mean $\pm S D$ & $\%$ RSD \\
\hline Chamber saturation time: $\mathbf{2 0} \mathrm{min}$ & $0.50 \pm 0.005$ & 1.13 & $0.72 \pm 0.005$ & 0.79 & $0.13 \pm 0.005$ & 4.22 & $0.28 \pm 0.005$ & 2.03 \\
\hline Chamber saturation time: $\mathbf{4 0} \mathrm{min}$ & $0.51 \pm 0.005$ & 1.11 & $0.73 \pm 0.005$ & 0.78 & $0.14 \pm 0.005$ & 4.02 & $0.30 \pm 0.55$ & 1.90 \\
\hline Wave length $280 \mathrm{~nm}$ & $0.52 \pm 0.0$ & 0.0 & $0.74 \pm 0.005$ & 0.77 & $0.14 \pm 0.00$ & 0.00 & $0.3 \pm 0$ & 0.0 \\
\hline Wave length $284 \mathrm{~nm}$ & $0.52 \pm 0.0$ & 0.0 & $0.74 \pm 0.005$ & 0.77 & $0.14 \pm 0.00$ & 0.00 & $0.30 \pm 0.005$ & 1.90 \\
\hline $\begin{array}{l}\text { chloroform:methanol:ethayl } \\
\text { acetate:hexane:ammonia } \\
(9: 3.5: 1.5: 1: 0.1, \mathrm{v} / \mathrm{v} / \mathrm{v} / \mathrm{v} / \mathrm{v})\end{array}$ & $0.52 \pm 0.005$ & 1.09 & $0.75 \pm 0.005$ & 0.76 & $0.14 \pm 0.005$ & 4.02 & $0.31 \pm 0.005$ & 1.84 \\
\hline $\begin{array}{l}\text { chloroform:methanol:ethaylacetate:hexane:ammonia } \\
(11: 2: 1: 1: 0.1, v / v / v / v / v)\end{array}$ & $0.51 \pm 0.005$ & 1.12 & $0.72 \pm 0.005$ & 0.79 & $0.13 \pm 0.005$ & 4.3 & $0.29 \pm 0$ & 0 \\
\hline
\end{tabular}

Table 4: Accuracy study of the proposed method.

\begin{tabular}{|c|c|c|c|c|c|c|c|c|c|c|c|c|}
\hline \multirow{2}{*}{ \% Level } & \multicolumn{4}{|c|}{$\begin{array}{l}\text { Amount Added } \\
\text { (ng/band) }\end{array}$} & \multicolumn{4}{|c|}{$\begin{array}{l}\text { Amount Recovered } \\
\text { (ng/band) }(n=3)\end{array}$} & \multicolumn{4}{|c|}{ 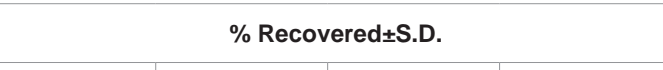 } \\
\hline & PCM & CLZ & DCL & FAM & $\mathrm{PCM}$ & CLZ & FAM & DCL & $\%$ PCM & $\% \mathrm{CLZ}$ & $\%$ FAM & $\% \mathrm{DCL}$ \\
\hline 0 & $1000+0$ & \multicolumn{3}{|c|}{$500+0$} & 994.48 & 495.47 & 496.73 & 501.38 & $99.44 \pm 1.38$ & $99.09 \pm 0.58$ & $99.34 \pm 1.19$ & $100.27 \pm 0.52$ \\
\hline 50 & $1000+500$ & \multicolumn{3}{|c|}{$500+250$} & 1498.81 & 747.89 & 744.73 & 749.28 & $99.88 \pm 0.92$ & $99.57 \pm 0.66$ & $98.94 \pm 0.93$ & $99.85 \pm 0.38$ \\
\hline 100 & $1000+1000$ & \multicolumn{3}{|c|}{$500+500$} & 1985.55 & 997.13 & 997.75 & 998.99 & $98.55 \pm 0.62$ & $99.42 \pm 0.51$ & $99.55 \pm 1.03$ & $99.79 \pm 0.96$ \\
\hline 150 & $1000+1500$ & \multicolumn{3}{|c|}{$500+750$} & 2489.83 & 1244.06 & 1245.07 & 1246.10 & $98.98 \pm 0.75$ & $98.81 \pm 0.87$ & $99.01 \pm 1.13$ & $99.22 \pm 0.85$ \\
\hline
\end{tabular}

appropriate RF value for PCM, CLZ, DCL and FAM was desired. Various mobile phases such as acetone-methanol, methanolchloroform acetic acid, methanol-toluene-ammonia, methanoltoluene-glacial acetic acid, toluene-ethyl acetate-methanol, methanolacetonitrile-glacial acetic acid were evaluated in different proportions. A mobile consisting of chloroform: methanol: ethyl acetate: hexane: ammonia (10:2.5:1.5:1:0.1, v/v/v/v/v) gave good separation of PCM, CLZ, DCL and FAM from its matrix. It was also observed that chamber saturation time and solvent migration distance were crucial in the chromatographic separation. Therefore, chloroform: methanol: ethyl acetate: hexane: ammonia (10:2.5:1.5:1:0.1, v/v/v/v/v) mobile phase with a chamber saturation time of $30 \mathrm{~min}$ at $25^{\circ} \mathrm{C}$ and solvent migration distance of $80 \mathrm{~mm}$ was used. Densitogram of PCM, CLZ,
DCL and FAM, photograph of TLC plate and three dimensional overlays of HPTLC densitograms of calibration bands of PCM, CLZ, DCL and FAM are depicted in figures (Figures 1-4).

\section{Validation}

\section{Linearity and calibration curves}

The method was found to be linear for PCM in concentration range of 500-3000 ng/band $(n=6)$ and for CLZ, DCL and FAM 250-1500 ng/band ( $n=6)$ respectively. (Figure 3) displays a threedimensional overlay of HPTLC densitograms of the calibration bands of PCM, CLZ, FAM and DCL at $282 \mathrm{~nm}$ (Figure 1). The regression data shown in (Table 1) reveal a good linear relationship over the concentration range studied, demonstrating the suitability of the 
Table 5: Assay results of marketed formulation.

\begin{tabular}{|c|c|c|c|c|}
\hline Formulation & Drug & $\begin{array}{c}\text { Amount } \\
\text { Taken } \\
\text { (ng/band) }\end{array}$ & $\begin{array}{c}\text { Amount Found } \\
\text { (ng/band) } \\
\text { (n=3) }\end{array}$ & $\begin{array}{c}\text { \%Amount of drug } \\
\text { found } \\
\text { Mean } \pm \text { SD } \\
(\mathbf{n}=\mathbf{3})\end{array}$ \\
\hline & PCM & 1500 & 1482.33 & $98.82 \pm 0.69$ \\
\cline { 2 - 5 } FASTRAN MR & CLZ & 750 & 743.66 & $99.15 \pm 1.13$ \\
\hline \multirow{2}{*}{ (Tablet) } & FAM & 300 & 295.00 & $98.33 \pm 1.00$ \\
\cline { 2 - 6 } & DCL & 1500 & 1485.33 & $99.02 \pm 0.85$ \\
\hline
\end{tabular}

method for analysis.

\section{Accuracy}

Accuracy was determined by the application of analytical procedure to recovery studies, where a known amount of standard is spiked into reanalyzed samples solutions. Results of the accuracy studies from excipients matrix are shown in table. Recovery values demonstrated the accuracy of the method in the desired range.

\section{Precision}

In all instances, RSD values were less than $2 \%$, confirming the precision of the method. Repeatability of the scanning device was studied by applying and analyzing sample seven times. RSD was less than $2 \%$, which was well below the instrumental specifications. Summary of validation parameters are shown in (Table 2). The RSD values obtained were less than $2 \%$, which was under the acceptance criteria of ICH method validation guideline $(<2 \%)$. The results indicated that the method is repeatable and reproducible.

\section{Limit of detection and limit of quantification}

Under the experimental conditions used, the lowest amount of drug that could be detected LOD was found to be $35.98 \mathrm{ng} / \mathrm{band}$, $99.74 \mathrm{ng} / \mathrm{band}, 58.63 \mathrm{ng} / \mathrm{b}$ and and $50.93 \mathrm{ng} / \mathrm{band}$ for PCM, CLZ, DCL and FAM respectively and LOQ was found to be $109.05 \mathrm{ng} / \mathrm{band}$ $302.25 \mathrm{ng} / \mathrm{band}, 177.69 \mathrm{ng} / \mathrm{b}$ and and $154.35 \mathrm{ng} / \mathrm{band}$ for PCM, CLZ, DCL and FAM respectively. It indicate that the nanogram quantity of all the drugs can be estimated accurately and precisely which means that the method is sensitive.

\section{Specificity}

There was no interfering peak at the RF value of PCM, CLZ, DCL and FAM from excipients added in the synthetic formulation. In addition, there was no interference from excipients present in the commercial formulation, thereby confirming the specificity of the method.

\section{Robustness}

The low values of RSD obtained after introducing small, deliberate changes in parameters of the developed HPTLC method confirmed its robustness. The robustness data of the proposed method are shown in (Table 3).

\section{Analysis of marketed formulation}

Marketed formulation was analyzed using proposed method which gave percentage recovery of $98.46 \%, 98.26 \%, 98.09 \%$ and 99.01\% for PCM, CLZ, DCL and FAM respectively. No interference from the excipients present in the marketed tablet formulation was observed. Assay results and densitogram of marketed formulation are shown in (Tables 4 \& 5 \& Figure 5).

\section{Conclusion}

A selective, sensitive, accurate and precise high performance thin layer chromatography method has been developed for the simultaneous identification and quantification of chlorzoxazone, paracetamol, famotidine and diclofenac potassium in their combined pharmaceutical dosage form. The method was successfully validated in accordance with ICH guidelines. It can be conveniently used for routine quality control analysis of chlorzoxazone, paracetamol, famotidine and diclofenac potassium in marketed tablet without any interference from excipients. The method might be used to determine the purity of drug available from various sources.

\section{Acknowledgement}

Authors are grateful to Sun Pharmaceutical Pvt. Ltd. and Alembic Pharmaceutical Pvt. Ltd., Vadodara, Gujarat, India for providing gift sample of standard Chlorzoxazone, Paracetamol, Famotidine and Diclofenac Potassium. The authors are very thankful to SICART and Indukaka Ipcowala College of Pharmacy, New Vallabh Vidyanagar, for providing necessary facilities to carry out research work.

\section{References}

1. Gopinath R, Rajan S, Meyyanathan SN, Krishnaveni N, Suresh B. A RPHPLC method for simultaneous estimation of paracetamol and aceclofenac in tablets. Ind J Pharm Sci. 2007; 69: 137-140.

2. Khatal LD, Rajage AD, More HN, Dhaneshwar SR, Polawar AR. Validated HPLC method for simultaneous quantitation of paracetamol, diclofenac potassium and famotidine in bulk drug and formulation. Int J Pharm Drug Ana. 2014 ; 2: 633-640.

3. Pawar SJ, Kale AP, Amrutkar MP, Jagade JJ, Pore NS, Bhosale AV. HPTLC estimation of Paracetamol, Diclofenac Sodium and Chlorzoxazone in Tablet dosage form. Asian J Research Chem. 2009; 2: 299-301.

4. Khatal LD, Kamble AY, Mahadik, MV, Dhaneshwar SR. Simultaneous Quantitation of Paracetamol, Diclofenac Potassium and Famotidine in Tablet Formulation. J AOAC Int. 2010; 93: 765-770.

5. Gowramma B, Rajan S, Muralidharan S, Meyyanathan SN, Suresh B. A validated RP-HPLC method for simultaneous estimation of paracetamol and diclofenac potassium in pharmaceutical formulation. Int $\mathrm{J}$ Chem Tech Res. 2010; 2: 676-680.

6. Dighe VV, Sane RT, Menon SN, Tambe HN, Pillai S, Gokarn VN Simultaneous determination of diclofenac sodium and paracetamol in a pharmaceutical preparation and in bulk drug powder by high performance thin-layer chromatography. J Planar Chromatogr-Modern TLC. 2006; 19: 443-448.

7. Sharma M, Sharma S. Determination and validation of UV spectrophotometric method for estimation of paracetamol and diclofenac sodium in tablet dosage forms using hydrotropic solubilizing agents. Int J Pharm Tech Res. 2011; 3 : 244-247.

8. Siddiqui FA, Arayne MS, Sultana N, Qureshi F. Development and validation of stability-indicating HPLC method for the simultaneous determination of paracetamol, tizanidine and diclofenac in pharmaceuticals and human serum. J AOAC Int. 2011; 94: 150-158.

9. Shaikh KA, Devkhile AB. Simultaneous determination of aceclofenac, paracetamol and chlorzoxazone by RP-HPLC in pharmaceutical dosage form. J Chromatogr Sci. 2008; 46: 649-652.

10. Umarkar AR, Mehta SA, Chaple DR, Thote LT. Simultaneous estimation of famotidine and diclofenac potassium by uv spectrophotometer using multicomponent method. J Pharmacy Res. 2011; 4: 978-982.

11. Mehta SA, Umarkar AR, Chaple DR, Thote LT. Development of UV spectrophotometric methods for simultaneous estimation of famotidine and diclofenac potassium in combined dosage form using simultaneous equation method. J Pharmacy Res. 2011; 4: 2045-2051. 
12. Puranik M, Hirudkar A, Wadher SJ, Yeole PG. Development and validation of spectrophotometric methods for simultaneous estimation of tramadol hydrochloride and chlorzoxazone in tablet dosage form. Indian J Pharm Sci. 2006; 68: 737-739.

13. Manure JY, Sayyed AG, Tamboli AM, Ravetkar AS, Mohite SK. Analytical method development of Tramadol hydrochloride and Chlorzoxazone in bulk and its formulation. J Pharmacy Res. 2010; 3: 2296.

14. Patel J, Patel P. RP-HPLC method development and validation for the estimation of diclofenac sodium, tramadol hydrochloride and chlorzoxazone from their combined tablet dosage form. Int J pharmacy Pharm Sci. 2014; 6.

15. Shah DA, Suthar DJ, Baldania SL, Chhalotiya UK, Bhatt KK. Development and validation of liquid chromatographic method for estimation of ibuprofen and famotidine in combined dosage form. Int scholarly res. Notices. 2012.

16. Venkatesh KV, Yuvaraj G, Nema RK. Simultaneous estimation of Paracetamol, Chlorzoxazone and Aceclofenac in pharmaceutical formulation by HPLC method. Int J Chem Tech Res. 2009; 1: 457-460.

17. Yadav SS, Jagtap AS, Rao JR. Simultaneous determination of paracetamol lornoxicam and chlorzoxazone in tablets by high performance thin layer chromatography. Scholars Res. Library. 2012; 4: 1798-1802.

18. Mehta KC, Shyam Kumar B, Dubey A. Development and validation for simultaneous estimation of famotidine and diclofenac poatassium in combined tablet dosage form by first order derivative method. Int J Res Pharmacy and chemistry. 2012; 2.

19. Dhaneshwar SR, Bhusari VK. Validated HPTLC method for simultaneous estimation of diclofenac sodium and misoprostol in bulk drug and formulation. Asian J Pharm and Biological Res. 2011; 1: 15-21.

20. Karthik A, Subramanian G, Ranjith Kumar A, Udupa N. Simultaneous estimation of paracetamol and domperidone in tablets by reverse phase HPLC method. Indian J Pharm Sci. 2007; 69: 142-144.
21. Rajput MP, Bharekar VV, Yadav SS, Mulla TS, Rao JR. Validated HPTLC method for simultaneous estimation of diclofenac potassium and metaxalone in bulk drug and formulation. Int J Comprehensive Pharmacy. 2011; 12.

22. Nayak S, Sarangi RR, Panda SK, Dash AK, Rath SK, Rath S. UVspectrophotometric method for simultaneous estimation of paracetamol and ondancetron in bulk and their formulation. Int J Biological \& Pharm Res. 2011; 2: $45-49$.

23. Patel R, Tanna R, Thumar K. HPTLC Method for simultaneous estimation of ibuprofen and famotidine from tablet dosage form, Inventi Rapid: Pharm Anal \& Quality Assurance. 2012, 3.

24. Sane RT, Gadgil M. Simultaneous determination of paracetamol, chlorzoxazone and nimesulide by HPTLC. J Planar Chromatogr-Modern TLC. 2002: 150.

25. Reddy PB. Simultaneous estimation of nimesulide and chlorzoxazone in pharmaceutical formulations by RP-HPLC Method. Int J ChemTech Res. 2009; 1: 283-285

26. Zarghi A, Shafaati A, Foroutan SM, Khoddam A. Development of a rapid HPLC method for determination of famotidine in human plasma using a monolithic column. J Pharm and Biomedical Anal. 2005; 39: 677-680.

27. Novakovic J. High-performance thin-layer chromatography for the determination of ranitidine hydrochloride and famotidine in pharmaceuticals. J Chromatogr. 1999; 846: 193-198.

28. ICH, Validation of Analytical Procedures: Text and Methodology; Q2R1. International Conference on Harmonization, Geneva, Switzerland. 2005.
Austin Chromatogr - Volume 4 Issue 1 - 2017

ISSN 2379-7975 | www.austinpublishinggroup.com

Chhalotiya et al. () All rights are reserved
Citation: Chhalotiya UK, Patel DB, Shah DA, Mehta FA and Bhatt KK. TLC Method for Simultaneous Quantification of Chlorzoxazone, Paracetamol, Famotidine and Diclofenac Potassium in their Combined Dosage Form. Austin Chromatogr. 2017; 4(1): 1044 